\title{
THE NEED FOR ESTABLISHMENT OF A FAMILY COURT IN MALAYSIA: AN APPRAISAL
}

\author{
'Ain Husna Mohd. Arshad" \\ Roslina Che Soh@Yusoff**
}

\begin{abstract}
The adjudication of family disputes by different courts with different jurisdictions in the present court system is ineffective in providing a comprehensive approach to the management of family-related disputes. Furthermore, the adversarial system of litigation of the present courts in Malaysia negates the possibility of resolving conflicts amicably. The establishment of a family court in Malaysia would be in line with the objective of the National Family Policy which encourages the sustainability of the family institution. Basically, this paper seeks to discuss the concept of family court and the need for its establishment in Malaysia. The paper will also briefly discuss the implementation of family court systems in Australia, Singapore and Egypt as these countries have a well developed family court system. The purpose is to learn from their experiences in providing a
\end{abstract}

Ph.D student at Ahmad Ibrahim Kulliyyah of Laws International Islamic University Malaysia.

Assistant Professor at Ahmad Ibrahim Kulliyyah of Laws International Islamic University Malaysia. 
comprehensive solution to resolve family related disputes in Malaysia.

Keywords: family, family court, family dispute resolution, mediation, reducing adversarial trials

\title{
KEPERLUAN MENUBUHKAN SEBUAH MAHKAMAH KELUARGA DI MALAYSIA: SATU PENILAIAN
}

\begin{abstract}
ABSTRAK
Penghukuman pertikaian keluarga oleh mahkamah berbeza dengan bidang kuasa berbeza dalam sistem mahkamah sekarang adalah tidak berkesan dalam memperuntukkan satu pendekatan yang menyeluruh kepada pengurusan pertikaian berkaitan keluarga. Lagipun, sistem litigasi pertentangan mahkamah Malaysia sekarang menafikan kemungkinan penyelesaian sengketa secara berbaik-baik. Penubuhan sebuah mahkamah keluarga di Malaysia akan selaras dengan tujuan Dasar Keluarga Nasional yang menggalakkan kemapanan institusi keluarga. Pada dasarnya, makalah ini mencari untuk membincangkan konsep mahkamah keluarga dan keperluan menubuhkannya di Malaysia. Makalah ini membincangkan secara ringkas pelaksanaan sistem mahkamah keluarga di Australia, Singapura dan Mesir kerana negara-negara ini mempunyai sistem mahkamah keluarga yang betul-betul maju. Ia bertujuan untuk mempelajari daripada pengalaman mereka dalam mencadangkan sebuah penyelesaian yang menyeluruh dalam menyelesaikan pertikaian berkaitan keluarga di Malaysia.
\end{abstract}

Kata kunci: keluarga, mahkamah keluarga, penyelesaian pertikaian keluarga, pengantaraan, mengurangkan perbicaraan pertentangan 


\section{INTRODUCTION}

Family is defined by Hammūdah as a special kind of structure whose principles are related to one another through blood ties or marital relationships, and whose relatedness is of such nature as to entail mutual expectations that are prescribed by religion, reinforced by law and internalized by the individual. ${ }^{1}$ Family matters, even though regarded as private matters, do not mean that society has no concern at all. Where situations arising in a family become unmanageable, the authority which represents the society at large may take necessary actions to control or handle family conflicts in order to maintain stability in the family, which in return provides stability in society.

In Malaysia, the National Family Policy advocates the concept of "family welfare" which is based on family values such as compassion, honesty, fairness and equality regardless of status, gender and age. In a broader scope the policy will act as a catalyst in urging all stakeholders to focus on 'family perspectives' in plans, strategies and development to be implemented. The policy's objective is to develop a prosperous family, healthy and resilient to ensure social stability. ${ }^{2}$ Thus, one of the ways to enhance overall family and social stability is through the establishment of family court.

The suggestion to establish a family court in Malaysia has been heard since early 1980's. It was not given serious attention at that time. In recent years, the same suggestion has been mentioned again by many supporters of NGOs, a few public figures, academicians and writers. In 1999, the High Court of Kuala Lumpur established its own family division dedicated to hear family cases. To some extent, this indicates that the Malaysian court has started to distinguish family disputes from other civil disputes that are competing to get settlement in court. On the other hand, the Syariah court could be considered as a family court for Muslims due to the power and jurisdiction conferred on it which mainly cover family matters or Muslim personal laws.

\footnotetext{
$1 \quad$ Hammudah, 'Abd al-Āti (1995). The Family Structure in Islam, American Trust Publications, p.19.

2 "National Family Policy," Lembaga Penduduk dan Pembangunan Keluarga Negara, http://www.lppkn.gov.my (accessed November 9, 2012).
} 
The idea of a family court is based on the grounds that family disputes involve different approaches as compared to resolution of other civil matters due to their distinct features. These features include, firstly, future arrangement of the family life after divorce. Secondly, the involvement of interests of the third party primarily the children, who will be the most affected by the family breakdown. Thirdly, the involvement of the family with court proceedings and lawyers. Fourthly the legal process is regarded as an undesirable forum for the resolution of family disputes as the disputes also concern a few non-legal issues related to life. ${ }^{3}$ According to Molly Cheang, family disputes also involve parties' proximity, emotional strains and bitter hatred against each other, which need to be resolved through a comprehensive approach in order to maintain peace and happiness of the family involved. Therefore, it is not only legal issues that arise, but also the emotional feelings and psychological effects that might become serious and ultimately affect the whole institution of family. ${ }^{4}$ It is not proper to resolve legal issues only while other aspects are ignored. This is because family institution is the fundamental part of society.

\section{FAMILY COURT DEFINED}

According to Brown, family court is defined as an integrated and unified jurisdiction in a single court with competence over all aspects of family matters. It includes juvenile delinquency, divorce, nullity and separation, guardianship and custody disputes, maintenance, matrimonial property disputes, domestic violence, children's issues and adoption. Instead of jurisdiction over such matters being fragmented between several courts, it is consolidated in a single court, even though there may be a need to have specialized divisions or sections within that one court. ${ }^{5}$

$3 \quad$ Dame Brenda Hale, David Pearl, Elizabeth J. Cooke \& Philip D. Bates (2002). The Family, Law and Society Cases and Materials, $5^{\text {th }}$ Edition, Lexis Nexis, p. 227.

$4 \quad$ See Molly Cheang [1985]. “Family Court: Let’s Have It.” MLJ Jan-Jun cxlviii, cxlix.

$5 \quad$ L. Neville Brown, "The Legal Background to the Family Court," Vol. 6 (1966) The British Journal Of Criminology, 140. 
Besides the jurisdiction being integrated in a single court, this court also collaborates with other social service units that provide their services in court. It emphasizes the holistic approach of family dispute settlement whereby it integrates all aspects of the individuals involved and observes the case as a whole. It also promotes the less adversarial system of litigation, where the fundamental principle is the application of alternative dispute resolution such as mediation, conciliation and arbitration which is also known as sulh and tahkim under the Shariah.

\section{A GENERAL OVERVIEW OF THE ADMINISTRATION OF FAMILY LAW IN MALAYSIA}

Malaysia exercises the dual system of family law, family Law of Muslims and another one is of non-Muslims. The basis of this system originated from the diversity in the components of Malaysian citizens. Malaysia consists of people from various races, religions, customs and usage in family matters. Family law is the only area of law which divides the citizens based on religions. Due to the existence of the dual system of family law, different courts have been established to administer family law for Muslims and non-Muslims separately. The following paragraphs will discuss a few problems surrounding the administration of family law in Malaysia.

\section{The Civil Courts}

In Malaysia, the family constitutes the subject matter of a number of legislative enactments for the establishment of husband-wife and child relationships. As for the non-Muslims, all these are essentially found in the Law Reform (Marriage and Divorce) Act 1976. However, there are various other enactments which deal with specific areas, for instance, the Domestic Violence Act 1994 which regulates domestic violence cases. The Penal Code also contains provisions on family matters, particularly domestic violence. For child related cases various statutes are applicable such as the Adoption Act 1952, Guardianship of Infant Act 1961, Legitimacy Act 1961 and Child Act 2001. Other than that, Distribution Act 1958 and Inheritance (Family Provision) Act 1971, Married Woman 
and Children (Maintenance) Act 1950 and Courts of Judicature Act 1964 are also applicable.

When it comes to the process and proceedings, it is more complicated. In domestic violence cases, the proceedings commence by a wife are heard at the Magistrates' courts, but at the same time the High Court may hear petition for divorce as well. Protection orders, punishments and redress are dealt with by both the criminal and civil courts. ${ }^{6}$ Petition for divorce, nullity, custody, judicial separation, declaration of legitimacy, ${ }^{7}$ division and disputes over matrimonial property are heard at the High Court. ${ }^{8}$ Applications for maintenance are normally handled by the magistrates and sessions courts but the High Court has jurisdiction as well. ${ }^{9}$ Adoption cases are heard at either the High Court or the Sessions Courts. ${ }^{10}$ Applications and succession cases are heard either before the subordinate courts or the High court depending on the value of the estate. ${ }^{11}$ Finally, cases involving juvenile delinquents are brought either before the Court for Children or magistrates courts depending on the nature of the case. ${ }^{12}$

Moreover, it has been claimed that the current practice of conciliation regulated under section 106 of the Law Reform (Marriage and Divorce) Act 1976 causes more problems rather than solutions. The parties feel that it was a forced mediation as it is mandatory for the couple to refer their case to the conciliatory body before the presentation of the divorce petition. There are no specific guidelines or procedures and the members of the conciliatory body change frequently. Therefore the parties have to repeat their matrimonial pain every time the new members are appointed. ${ }^{13}$

\footnotetext{
Domestic Violence Act 1984, ss. 2, 4, 10, 11, 12 \& 13. Legitimacy Act 1961, s. 5.

Law Reform (Marriage and Divorce) Act 1974, s. 2(1).

Married Women and Children (Maintenance) Act 1950, s. 2; Law Reform (Marriage and Divorce) Act 1976, ss. 2(1) \& (2).

Adoption Act 1952, s. 10.

Inheritance (Family Provision) Act 1971, s. 2.

Child Act 2001, s. 2.

Zaleha Kamaruddin, Divorce Laws in Malaysia (Civil and Shariah), Malayan Law Journal, 2005, p. 113.
} 


\section{The Syariah Courts}

As for Muslims, there are Administration of Family Law Enactments in various states and also Administration of Syariah Enactments in each state that deal with procedures. The jurisdictions of Syariah Subordinate courts and Syariah High Courts as well as Syariah Appeal courts for each state in Malaysia are also contained in different statutes based on the states. For instance, for the state of Selangor, it is contained under the Selangor Administration of Islamic Enactment 1989; and for Federal Territories, the relevant law is the Administration of Islamic Law (Federal Territories) Act 1993.

Similar to the situation prevailing in civil courts, the administration in the Syariah courts too is sometimes confusing. It is known that the Syariah courts generally adjudicate cases on marriages, divorces and distribution of property. The application for divorce, judicial separation, maintenance upon divorce, guardianship of children, legitimacy, harta sepencarian and distribution of property should be made to the Syariah High Court. ${ }^{14}$ However, the Syariah Subordinate courts also have the same jurisdiction as the Syariah High Court and the only difference is regarding the amount or value of the subject matter in dispute. ${ }^{15}$ Domestic violence cases involve criminal action over which the Syariah court has limited jurisdiction. This has caused confusion and frustration to the victims of domestic violence because it requires the victim to go to courts of different jurisdictions which consequently result in more pain, harm and hardship to the victim. ${ }^{16}$ These situations also create a level of misperception regarding the integrity of the Syariah court.

However, due to the nature of Syariah court that specializes in the application of mediation which is known as sulh, amicable settlement has been successfully practiced in many states. They are able to reconcile many estranged couples, and in case of divorce, peaceful negotiation is made pertaining to future arrangements. A specific manual for sulh has been provided in order to standardize the procedure carried out by the

Administration of Islamic Law (Federal Territories) Act 1993, s. 46.

Ibid., s. 47.

Abu Bakar Munir \& Nor Aini Abdullah, "Domestic Violence and The Need For A Family Court” [1995] 4 CLJ lxxv (Nov), p.lxxxi. 
sulh officers. ${ }^{17}$ In the first year of its practice in the state of Selangor, there were 1529 cases registered with 1416 cases (92\%) successfully concluded. A total of 1029 cases out of 1416 achieved settlement by means of mediation which is equivalent to $67.3 \%{ }^{18}$ Unfortunately, due to non-uniformity of Islamic laws between states, some states are left behind, such as the state of Negeri Sembilan, where the implementation of mediation did not reach the target. ${ }^{19}$

\section{THE NEED FOR A FAMILY COURT}

With regard to the existing system of family law as briefly discussed above, it is our view that improvements are needed in order to preserve the future of the family institution, even after separation. Thus, the establishment of family court is timely and in line with the National Family Policy.

The existing system of family justice system as expounded earlier has caused hardship to the parties. Not only are they subjected to too many statues governing family relations in Malaysia, but they also have to run from one court to another in order to resolve a few issues originating from a single case of divorce. This has caused confusion and frustration to the parties. The time consumed and cost incurred are not promoting the welfare and well-being of the family members.

The present system also lacks concentration and specialization due to the reason that different courts hear different matters. Thus, judges are not able to hear and determine the case as a whole and the parties

$17 \quad$ See Sheikh Ghazali Abdul Rahman, "Penyelesaian Kes-kes Kekeluargaan Melalui Manual Kerja Sulh” in Undang-undang Keluarga Islam edited by Abdul Monir Yaacob and Siti Shamsiah Md Supi, Institut Kefahaman Islam Malaysia, 2006, pp. 243-260.

Nora Abdul Hak, "Family Mediation in Asia: A Special Reference to the Law and Practice in Malaysia” Vol. 15 No. 1 (2007) IIUM Law Journal, p.130.

19 See Wan Siti Asmak bt Wan Dollah, "The Importance of Mediation in Settling Divorce Cases" in Islamic Family Law: New Challenges in the $21^{\text {st }}$ Century, edited by Zaleha Kamaruddin, Research Centre, IIUM, 2005, p. 172. 
have to repeat the same issues, problems and expectations each time they deal with different officers and judges. There is also a possibility that some issues are left unresolved. Therefore it is necessary for the family court to have an integrated jurisdiction over all family related issues that also include cases on domestic violence and juvenile delinquency. The court must be presided over by a specialist judge with adequate legal jurisdiction and authorization to handle all family disputes. This can expedite the resolution of family disputes and reduce backlog of cases. Family court would also promote collaboration between lawyers and experts in the process of investigation.

The adversarial system of litigation also leaves traumatic effects on the family members, especially children. Many authors and scholars, while discussing the philosophy of the family court, view that family disputes and issues often present complex questions involving the analysis and prediction of human behavior that cannot be resolved by the simple application of a legal formula. Thus it is suggested that the family court should introduce a therapeutic approach..$^{20}$ The court's role should resemble a therapist who is responsible for finding a cure, rather than to give a verdict on who is right and who is wrong. The application of mediation and conciliation as an alternative to family dispute resolution encourages the parties to resolve their cases amicably and harmoniously. It provides an opportunity to achieve a win-win situation for both parties and obtain more satisfaction. This approach is healthy not only for the parties but also for the children who could be most affected by their parents' separation.

It is agreed by many authors and scholars that the establishment of the family court would be more effective, economical, cost-efficient, more convenient for the parties and provide a solution to resolve cases expeditiously due to the simple process of adjudication involving less formalities. ${ }^{21}$ The mobility cost is also less because there is no need to go to courts of different jurisdictions.

\footnotetext{
20 Molly Cheang, “Family Court: Let’s Have It” [1985] MLJ Jan-Jun cxlviii, p. clii.

$21 \quad$ Kamala Bhaie, Family Law in Malaysia, Lexis Nexis, 2009, p.17; Muhammad Nizam Awang@Ali, “Mahkamah Keluarga Di Malaysia: Suatu Pandangan” [2004] I KANUN 20, p. 21; R.R. Chelvarajah, "Family Court” <http://www.malaysianbar.org.my>
} 
It is also claimed that one of the main purposes of the family court is to mediate all disputes and matters pertaining to family life which includes domestic violence cases. It should expedite domestic violence cases because there is no need to apply for order or redress from two different courts, with two different procedures. At the same time, the court would act as a mediator to aid the victim to handle the situation. ${ }^{22}$ Another crucial issue found in the existing system is the jurisdictional conflict between the Syariah court and the civil court in cases of divorce due to conversion of either spouse into Islam. Under the Islamic law, if a husband or wife who married under a non-Islamic law embraces the Islamic faith and the other party does not follow him or her during the period of iddah, the marriage will automatically come to an end, i.e. separation takes place immediately by way of faraq. ${ }^{23}$ However in Malaysia, a person who has embraced Islam is still bound by his or her former civil law marriage. He or she cannot obtain a divorce under the Law Reform (Marriage and Divorce) Act 1976. This is because under s. 51 of the LRA, the law only gives the right to apply for divorce to the party who has not converted to Islam and the Muslim party is also prevented from petitioning for a divorce because according to s. 3(3), the LRA is not applicable to Muslims. However, where the non-Muslim party has obtained a decree of divorce based on the conversion to Islam of the other party, the decree issued by the court is valid against the party who is converted to Islam. It should follow that if the decree is enforceable against the Muslim party, the ancillary orders should also be enforceable against that party.

Therefore if the civil court granted a maintenance order, then the husband should pay the maintenance for the wife until she re-marries or for her full life; or she is living in adultery with any other person. ${ }^{24}$ Similarly the converted wife is also expected to maintain her husband in particular circumstances. ${ }^{25}$ Whereas, under Islamic law, the husband is

\footnotetext{
$22 \quad$ Abu Bakar Munir \& Nor Aini Abdullah, "Domestic Violence and The Need For A Family Court” [1995] 4 CLJ lxxv (Nov), p.lxxxi.

23 Shamsuddīn Muhammad bin Muhammad Al-Khațīb Al-Sharbini, Mughni Al-Muhtāj ila Ma'rifati Ma'āni Alfaz Al-Minhaj, Vol. 4, Dār Al-Kutub Al-' Ilmiyyah, First Edition, 1994 at 320-322.

24 LRA, s. 82(1).

25 LRA, s. 77(2).
} 
only obliged to pay maintenance during the period of iddah and there are no such cases where the wife is ordered to maintain her former husband. Although section 46 of the Islamic Family Law (Federal Territories) Act 1984 gives the Syariah court power to confirm that the conversion to Islam by either party to a non-Muslim marriage may dissolve the marriage, this does not seem to be effective to terminate the marriage as far as the other party is concerned. Suggestions have been made to amend section 3 and section 51 of the LRA to allow the convert spouse to apply for divorce under the LRA. ${ }^{26}$

It has been suggested by Yang Berbahagia Dato’ Haji Abdul Hamid bin Haji Mohamad, the former Chief Justice of Malaysia, that, in cases involving Syariah law and civil law, the Syariah court judges and the civil court judges shall sit together to hear and decide the issues. ${ }^{27}$ Since the civil court is the court that administers the civil marriage, the case could be heard at the civil court but at the same time calling an opinion from Syariah court judges on specific matter. Dato' Haji Abdul Hamid J. also mentioned that the time has come for us to think seriously about the suggestion to consolidate the two courts' system event though the process might be complicated. ${ }^{28}$ This suggestion was also agreed to by Tan Sri Harun Hashim J. who suggested that the ideal solution is a Family Court for all family law cases for both Muslims and non-Muslims, conferred with criminal and civil jurisdictions. However, due to some jurisdictional limitations in the present system, Tan Sri Harun Hashim J. mentioned that a practical approach at the initial and immediate stage is

26 Ahmad Mohamed Ibrahim, The Administration of Islamic Law in Malaysia, Institute of Islamic Understanding Malaysia, 2000, p.357; Najibah Mohd Zin, "Pertukaran Agama: Kesan Terhadap Status Perkahwinan dan Tuntutan Relief Sampingan” in Manual Undangundang Keluarga Islam edited by Abdul Monir Yaacob and Siti Shamsiah Md. Supi, IKIM, 2006, p.195; and Nuraisyah Chua Abdullah, Conversion to Islam - Effect on Status of Marriage and Ancillary Reliefs, International Law Book Series, 2004, p.50.

27 Dato' Haji Abdul Hamid bin Mohamed, “Civil and Shariah Court in Malaysia: Conflict of Jurisdiction,” [2002] 1 MLJ cxxx.

28 YA Dato’ Abdul Hamid Haji Mohamed, “Perkembangan Terkini Mahkamah Syariah di Malaysia” in Sistem Kehakiman Islam edited by Abdul Monir Yaacob, Institut Kefahaman Islam Malaysia, 2001, p.70. 
to establish a Family Court administratively within the confines of existing law. ${ }^{29}$

It is agreed that the establishment of Family Court would inevitably be a complicated process and procedure. Therefore, if it is to be done in the near future, we need a more practical approach that does not require a massive amendment of laws, but could be administered within the limitations of the existing law. The most feasible way is by having a family court within the civil court to deal with non-Muslim cases, and another family court is established within the Syariah court to deal with Muslim cases. In certain exceptional circumstances where the issue involves Syariah law and civil law such as dissolution of marriage by conversion, judges from the Syariah court and civil court may sit together to determine the issue of divorce and ancillary matters. However, until and unless the constitutional amendment is made, this will not happen. Nevertheless, it is viewed that the ideal solution mentioned by Tan Sri Harun Hashim J. above, i.e., to have a family court with integrated jurisdiction over Muslims and non-Muslims, is the best solution. ${ }^{30}$

\section{FAMILY COURTS IN OTHER COUNTRIES}

There are a number of countries that already have a well organized family court with comprehensive jurisdiction over all family related issues. Among these countries are Australia, New Zealand, United Kingdom, Canada and Singapore. Family court has also been established in some Muslim countries such as Egypt and Qatar. For the purpose of this paper, only three countries will be highlighted, i.e. Egypt, Australia and Singapore.

$29 \quad$ Harun Mahmud Hashim, "Time Has Come to Establish Family Courts” in The Benchmark, edited by Zuraidah Omar, Peninsula Digital Sdn Bhd, 2007, pp. 52-55.

30 Based on an interview with the Family Court Judge in Kuala Lumpur, the Judge, Datin Yeoh, felt that conversion is not a major issue because the convert spouse usually obtained a divorce or judicial separation from the civil court, following the petition filed by the non-convert spouse. Therefore the ancillary matters are also determined by the civil court. Commenting on the suggestion made by Tan Sri Harun Hashim, she mentioned that such case is not possible until an amendment is made to the Federal Constitution. 


\section{Family Court Of Singapore}

The idea of a family court in Singapore has been mooted since 1975 by Review Committee of the Women's Charter. However, their recommendations have never been published. ${ }^{31} \mathrm{~A}$ decade later, the creation of a family court was again mooted by a group of Singaporean academics that cited the undesirable situation of family affairs under the legal system. ${ }^{32}$

The proposal to establish a family court faced some resistances at the beginning. The opponents had cited reasons such as the infrequency of complex cases and an increase in costs. Some had argued that England had not practiced such a concept of family court and that the traditional dependency of Singapore on English law meant that Singapore should follow England's pattern. ${ }^{33}$

The Family Court of Singapore was set up on $1^{\text {st }}$ March 1995 as a specialized court for family members to seek legal redress for all familyrelated disputes. The philosophy of the Family Court of Singapore is to protect family obligations so that family ties may be strengthened and preserved. Family obligations are those duties that have to be discharged by each spouse to the other, by parents to their children, and vice versa, and by each individual to their family members. These include a parent's responsibility to maintain, nurture and care for his children, an adult child's duty to maintain his parents, a husband's duty to maintain his wife, a wife's duty to honour her husband and the duty of all family members to treat each other with care, concern and respect. ${ }^{34}$

Initially, when the Family Court first began hearing cases, it only dealt with applications for maintenance and protection orders under the Women's Charter. In 1996, the Chief Justice made an order transferring all matrimonial proceedings under Part X of the Women's Charter and

\footnotetext{
31 Doris Lai-Chia Lee Mui, “The Family Court of Singapore,” [1995] SJLS 655.

32 Adrian Loke, "Mediation in the Family Court," June (1998) The Singapore Law Gazette, p. 29.

Ibid., 30

"Family Court," The Subordinate Court of Singapore http:// app.subcourts.gov.sg/family page. aspx?pageid=3656 (accessed December 10, 2011).
} 
guardianship proceedings under the Guardianship of Infants Act to the Family Court from the High Court. Now, the Family Court is a unified family court, dealing with all family proceedings in Singapore. Its jurisdiction covers cases of adoption, divorce, nullity, judicial separation, guardianship and custody, division of matrimonial assets, personal protection orders, maintenance of spouse and children, and enforcement of maintenance order. ${ }^{35}$

The Family Court also has jurisdiction to deal with certain matters involving Muslim parties. Prior to the amendments of the Administration of Muslim Law Act 1999, the High Court did not have jurisdiction to hear and try any civil proceedings which came under the jurisdiction of the Syariah Court. The amendments spell out that the High Court shall have no jurisdiction in the matters relating to marriage, divorce, betrothal, nullity of marriage or judicial separation involving Muslim parties or parties who were married under the Muslim law. ${ }^{36}$ Those matters shall be an exclusive jurisdiction of the Syariah Court. The effect of the amendment is that it confers concurrent jurisdiction on the High Court to deal with maintenance, custody of children and division of property on divorce involving Muslim parties. ${ }^{37}$ It also provides for the registration of orders made by the Syariah Court in the District Court after which such orders may be enforced as District Court orders. ${ }^{38}$ The effect of concurrent jurisdiction is that parties will try to have their case heard at the court that they perceive will be most favourable to them.

The Family Court also offers a harmonious and holistic approach to dispute resolution. Mediation is also conducted in the family court in order to assist the parties to resolve their dispute harmoniously. During the process of mediation, the parties will be assisted to identify the area where they both agree and then to negotiate on the area that they disagree. Once they reach a settlement, it will be recorded as a consent order. ${ }^{39}$ The Family Court mediation has been proven successful since the very beginning of the establishment of family court in 1995. From the total

\footnotetext{
$35 \quad$ Ibid.

36 Singapore Administration of Muslim Law Act, s. 35(2).

37 Supreme Court of Judicature Act, s. 17A(2).

38 Administration of Muslim Law Act, s. 53.

39 Leong Wai Kum, Principles of Family Law in Singapore, Butterworth Asia, 2000, pp. 11-12.
} 
number of 5452 cases in 1995, 4640 cases were successfully mediated, which is equivalent to $85.1 \%{ }^{40}$

The Report on the Study Tour of the Family Court of Singapore written by Petra Oon Beng Ai may illustrate how the Family Court looks like. It is a four storey building, standing next to the Subordinate Court. The whole set up of the Family Court is people and user friendly. There are many court rooms housed at various floors. It has two family registries located in a large open area in the middle of the first floor where counters are manned by personnel to guide laymen with their queries and various applications. There are ample comfortable seats for the queues to wait until the number is called. The waiting time is approximately 15 minutes. At that time, there were eight Judicial Officers consisting of seven District Judges and one Magistrate presiding in the Family Court. These judges hear and decide family cases and applications, mediate family disputes and take charge of various court programs and services. ${ }^{41}$

The family Court also has a secure children's room equipped with a caregiver who assists in keeping an eye on the children. The parents or guardians have to sign their children in and out of the room. Inside the children's room, story books and games are provided. There is also a separate lounge for men and women with televisions showing the supporting programs that the court is offering. ${ }^{42}$

During the recent study visit, it was found that the number of Judges has been increased to 27, comprising of 18 District Judges and 9 ad-hoc judges. The Family Court is also manned by 20 mental health professionals, 8 maintenance mediators and 40 volunteer mediators, and 63 court supervisors, officers and staff. Mediation is an integral part of Family Court process which has become a very effective case management tool. Trials will be the last resort if mediation fails to give any resolution. There are three dedicated units conducting mediation in the Family Court. These are Family Resolution Chambers, Child Focused Resolution Centre and Maintenance Mediation Chambers. The first two

\footnotetext{
$40 \quad$ Lim Lan Yuan \& Liew Thiam Leng, Court Mediation in Singapore, Singapore, 1997, p. 53.

$41 \quad$ Petra Oon Beng Ai, "Report on the Study Tour of the Family Courts of Singapore” 2007 www.malaysianbar.org.my (accessed September 20, 2010).

$42 \quad$ Doris Lai-Chia Lee Mui, p.655.
} 
units are headed by Judges which are also known as Judge-led mediation for divorce and ancillary matters, while the third unit is conducted by dedicated trained mediators and a large pool of volunteer mediators for maintenance only. The Family Court also does a strong networking with external partners such as the Singapore Mediation Centre, the Ministry of Community Development, Youth and Sports' Family Service Centres and other voluntary welfare organizations. ${ }^{43}$

Practically, the Family Court of Singapore has become a onestop centre for the family. While the family members had to run between various subordinate courts and the High Court to get settlement for their matters previously, this situation does not occur any more.

\section{Family Court of Australia}

The Family Court of Australia was created by virtue of the Family Law Act 1975 and commenced its operation on $5^{\text {th }}$ January 1976. The creation of a Family Court was one of the major reforms introduced by the Family Law Act 1975, which involved a major change in family law, substantially and procedurally. ${ }^{44}$

Among the stimuli for the establishment of family court in Australia was a desire to have a uniform judicial system for the administering of family law throughout Australia, as opposed to a different system operating in each state. There was also growth in population and the considerable increase in workloads of all Australian courts, thus the creation of a specialist jurisdiction became necessary. ${ }^{45}$ Another substantial reason that necessitates a specialist family court is the new attitudes particularly in dealing with children. It needs some modification in traditional court procedures. It was also realized that family conflicts need different qualities of family lawyers and experts and the participation

\footnotetext{
$43 \quad$ The informations were collected during the study visit to the Family Court of Singapore on 21 ${ }^{\text {st }}$ May 2012.

$44 \quad$ Patrick Parkinson, Australian Family Law in Context, Commentary and Materials, $4^{\text {th }}$ Ed., Thomson Reuters (Professional) Australia Limited, 2009, p. 186.

$45 \quad$ Ibid., 67.
} 
of social workers, psychologists and marriage counsellors was seen as indispensable. ${ }^{46}$

The purpose of the Family Court of Australia, as Australia's superior court in family law, is to determine cases with the most complex law, facts and multiple parties, cover specialized areas in family law, and provide national coverage as the appellate court in family law matters. It consists of a Chief Justice, Deputy Chief Justice and other judges. In 1999, the Federal Magistrates Court was established. In 2000, applications for divorce began to be filed in the Federal Magistrates Court. By 2005, all divorces were filed and heard in the Federal Magistrates Court rather than in the Family Court, which is now a superior court. ${ }^{47}$

Jurisdiction of the Family Court includes a few challenging matters the trial judges now deal with on a regular basis. The Family court determines cases with complex law and facts including cases with jurisdictional issues, multiple parties or involving parties who are not parties to the marriage, bankruptcy cases, cases with complex commercial and valuation issues, specialized areas such as Hague Convention cases, special medical procedures and serious cases of child abuse. On the other hand, the Federal Magistrates Court which was established in 1999 hears divorce cases and less complex family disputes.

It is reported that the Family Court of Australia has started to provide a mediation service since January 1992. An evaluation report was subsequently published in March 1994. The study sample consisting of 149 mediated cases concluded within 18 months. The study concluded that mediation could be effective in resolving wide variety of disputes provided that it is conducted by trained mediators familiar with family law and problems related to separation. ${ }^{48}$

From an alternative way of dispute resolution, the government of Australia has lifted family mediation and the related approaches to primary dispute resolution (PDR). This shows the government's seriousness and active role in introducing a less adversarial system of

\footnotetext{
$46 \quad$ Geoff Monahan \& Lisa Young, Family Law in Australia, $6^{\text {th }}$ Edition, Lexis Nexis Butterworths, 2006, pp. 29-30.

$47 \quad$ Jennifer Boland, "Family Law: Changing Law for A Changing Society," vol. 81 (2007) The Australian Law Journal, 554.

48 Renata Alexander, "Family Mediation under the Microscope” Vol. 10 No.3 (1999) Australasian Dispute Resolution Journal 18.
} 
litigation in family cases. Professor Dale Bagshaw, a prominent scholar from the University of South Australia, claimed that the adversarial system of family law in many ways promote conflict over cooperation. The PDR emphasized parental responsibility and cooperation. The introduction of 'no fault' principle in divorce proceedings, provided under the Family Law Act 1975 is also an effort to ensure the effectiveness of PDR. ${ }^{49}$

The year 2006 saw the most significant reform to the Australian family law when a new act was introduced, that is the Family Law Amendment (Shared Parental Responsibility) Act 2006. The aim of the new Act is to further improve the family law system of Australia. The Family Law Amendment (Shared Parental Responsibility) Act 2006 which came into effect on 1 July 2006 makes important changes to the operation of the family law system, particularly through the establishment of Family Relationship Centres, and to the substantive law applied by courts exercising jurisdiction under the Family Law Act 1975. The primary purpose of the Act is to encourage shared parental responsibility after separation which is consistent with the best interests of the child, promote resolution of disputes outside court and enable parenting disputes to be conducted using a less adversarial and more child-focused approach. ${ }^{50}$

The Family Law Act 1975 mandates this approach in Division 12A of Part VII. This means a trial in a child-related proceeding is focused on the children and their future. It is flexible so that it can meet the needs of particular situations, anticipated to be less costly compared to traditional trials. Hence, it will also reduce the time in court. The key features of the less adversarial approach, which vary significantly from a traditional hearing include, among others, the judge controls the hearing process and its inquiry, not the lawyers. A family consultant, who was previously known as a mediator, is in court from the first day as an expert adviser to the judge and parties. The parties can speak directly to the judge to tell in their own words what the case is about and what they want for their

$49 \quad$ Dale Bagshaw, "The Move Towards Primary Dispute Resolution in Family Law: The Role of Government and Implication for Justice” Vol. 2 (1997) Flinders Journal of Law Reform 1.

$50 \quad$ Chambers of the Honourable Diana Bryant "Family Court of Australia Annual Report 2005-2006: Part 1- Chief Justice's Review” $<$ www.familycourt.gov.au> (accessed 27 February 2011). 
children. The judge, rather than the parties or their lawyers, decides how the trial is run. ${ }^{51}$

\section{Family Court of Egypt}

The Family Court in Egypt was introduced in 2004 with the aim of establishing the non-adversarial legal system, attentive to the best interests of the family, accessible, and affordable..$^{52}$ Law No. 10 of 2004, which is the law that introduced Family Court is essentially procedural law and does not amend the substantial regulations of marriage and divorce. Prior to the establishment of family court, there were problems of backlogs and delays, overloaded courts and inefficient systems that resulted in hardship especially for women due to the legal process which was intimidating. ${ }^{53}$

Art 2 of the above law provides that the Family Court shall be composed of three judges and assisted by two experts, one of them shall be a social worker and the other a psychologist and at least one of them must be a woman. The attendance of the two experts shall be obligatory in cases of divorce, judicial divorce, physical separation, annulment and voiding of marriage, the custody of a minor and his custodial home, protection and access, implementation of physical custody and relocation and also in cases of paternity and obedience.

The jurisdiction of Family Court is spelt out under Art 3 where it says that the Family Court shall have exclusive jurisdiction to hear all personal status cases that fall under the jurisdiction of the Summary Courts and First Instance Courts which generally cover matters of personal status.

\footnotetext{
51 "Less Adversarial Trials” Family Court of Australia: http:// www.familycourt.gov.au/wps/wcm/connect/FCOA/home/about/LAT/ (Accessed 20 August 2011).

$52 \quad$ Mulki Al Sharmani, "Family Courts in Egypt: Pathway of Women's Empowerment?" via http://www.pathwaysofempowerment.org/ Familycourts.pdf_(accessed 27 February 2011).

53 Dawoud S. El-Alami, "Establishment of Islamic Courts in Egypt” Vol. 11 [2004-2005] Yearbook of Islamic and Middle Eastern Law 229.
} 
Art 4 of the law establishes a dedicated Bureau for Family Affairs functioning as public prosecution before the Family Court and its Appeal Division. The law also establishes a Family Dispute Settlement Office that offers the parties advice and guidance in an attempt to resolve the disputes amicably and preserve the family unit. This office shall consist of a sufficient number of legal, social and psychiatric experts.

It is stated under Art 10 that the sessions of Family Court and Appeal Division shall be held in locations separate from other courts, equipped with all necessary facilities in accordance with the nature of the disputes.

As far as non-Muslims are concerned, Egypt has a significant number of Christians-Coptic Orthodox in its population. According to the International Religious Freedom Report 2006, there are three religions that are officially recognized in the country. Those are Islam, Christianity and Judaism. Accordingly, Muslim families are subject to Shariah, Christian families to Canon law and Jewish family to Jewish law. ${ }^{54}$

However, there have been instances where the Islamic law of divorce by way of khul' (divorce by redemption) was granted to the non-Muslim wife upon her petition before the Court after she had failed to obtain divorce from her Christian husband. In this case, both spouses were Coptic-Orthodox at the time they were married but the wife subsequently converted to Syrian-Orthodox..$^{55}$ Therefore Islamic law is applicable in this case because the non-Muslim husband and wife are not from the same sect and rite. The law provides that where the couple share the same sect and rite and have their own organized sectarian juridical institution, judgment will be passed in accordance with their law. ${ }^{56}$

A study has been conducted to make some assessment of the latest reform to Egyptian Family Law in 2004. Among the benefits of the new structural changes is that having a panel of three judges to review and adjudicate family cases can facilitate due and fair process. The study

\footnotetext{
$54 \quad$ International Religious Freedom Report 2006, www.unhcr.org (accessed 27 February 2011).

$55 \quad$ Cairo Court for Personal Status, Case No. 2627 of 2000, as quoted in Aznan Hasan, "Granting Khul’ For a Non-Muslim Couple in Egyptian Personal Status Law: Generosity or Laxity?” Vol. 18 [2003] Arab Law Quarterly 81.

$56 \quad$ Egyptian Law No. 462 of 1995, Art 6.
} 
found that members of the judicial panel tend to share with one another their knowledge and expertise in family law. The key to the success of this process is to have specialized and experienced judges who also have comprehensive and critical understanding of the laws that they are implementing. The new court system also has potential to provide speedy legal redress, particularly to female plaintiffs. On the other hand, the new Family Court also has some problems, such as the mediation officers being unable to play an effective role due to lack of an authoritative legal structure, adequate training and resources, enforcement mechanisms, and a supportive legal and societal environment. The current judges in the new courts do not work exclusively on family law cases, and some continue to be transferred to different types of courts. Therefore, recommendations have been made to overcome the problems, for instance, by strengthening the role of mediation officers and emphasizing the specialization of Family Court judges. ${ }^{57}$

\section{CONCLUSION}

Among the most frequently mentioned problems relating to the court system are the problems of jurisdiction, the high cost of legal fees, time spent in going from one court to another in different locations, and the inconvenience of dealing with legal personnel that only solved the problem partially and could not appreciate the long-term effects of the fractional solutions to family life. Thus, it can be concluded that there is a need for a family court in Malaysia due to these and other circumstances as laid down in the paper.

Based on the experiences of the Singapore Family Court, it is found that mediation has become the most effective solution for speedy disposal of cases because it has been integrated into the court process. It is systematically conducted by dedicated units and supported by a large pool of volunteer mediators. The fact that Singapore too practices a dual system of family law similar to Malaysia is noteworthy because there are some areas of family law where the Family Court and Syariah court share jurisdiction. Among the salient features of Family Court in 
Australia is the less adversarial trial (LAT) which has been incorporated into legislation. A handbook has been provided as a step by step guide to the LAT. Another noteworthy aspect is the structure of Family Court, where it is placed at the superior level as compared to the Singapore Family Court which is placed at the subordinate level. The Family Court in Australia is an appeal court for family matters and hears more complex issues, whereas ordinary cases of marriage, divorce and ancillary matters are heard at the Federal Magistrates Court. This structure can be studied in further detail should we need to establish more family law courts in the future. In Egypt, despite the recent creation of Family Court, a number of positive changes have been introduced, the most noticeable being the composition of three judges assisted by two experts in social work and psychology, and the requirement that at least one of them must be a female. Each of the experts must produce a report based on their specialization. It is observed that in all three countries, some form of cooperation with experts in family affairs and other fields of specialization is noted to be a common feature, that reflects a holistic approach to family dispute resolution.

Based on the discussion on family court in the three countries cited, the features and functions of family court can be summed up as a specialized court with integrated jurisdiction over all family-related disputes, that promotes a less adversarial or inquisitorial approach, encouraging harmonious and effective dispute resolution through mediation. It also collaborates with social service agencies and organizations that provide counselling and therapeutic approaches to resolving family disputes.

Thus, in view of the diverse aspects of human nature, societal needs, and the distinct features of family disputes, it is recommended that family disputes should be handled in a specialized court that applies a different set of procedures that are distinct from those applied in civil disputes. However, due to constitutional limitations in Malaysia, there may be a need for two different structures of family court to be established, one within the civil courts and the other within the Syariah courts. It is not necessary that this court be called a 'Family Court' because it may even begin with a small division. What is important is that the features and functions referred to above must exist in that court or division.

It is suggested that the authorities should, as a primary step, establish a family court committee to discuss this proposal seriously. This committee shall consist of experts in family matters such as judges from 
civil and Syariah courts, lawyers, court officers, mediators, psychologists, academicians and other relevant members from the legal fraternity. Such a body could give serious consideration to realizing the idea of a family court and expedite taking necessary steps to amend the relevant laws. The establishment of family court in Malaysia will reflect the aspiration of National Family Policy that prioritizes family perspective in the development of laws, policies and procedures. 